\title{
Role of peptidoglycan in the pathogenesis of Staphylococcus saprophyticus in mice
}

\author{
Harith J.F. Al-Mathkhury* \\ May T. Flaih** \\ Athra S. Fleih***
}

Date of acceptance 19/9/2007

\begin{abstract}
The pathogenicity of $S$. saprophyticus was studied in mice. A group of white mice were injected transurethrally using a catheter with $S$. saprophyticus $S_{67}$ cell suspension in a concentration reached $10^{9} \mathrm{CFU} / \mathrm{ml}$. concomitantly, the role of its peptidoglycan in the pathogenicity was studied by injecting another group of mice with $0.3 \mathrm{mg} / 0.2 \mathrm{ml}$ of partially purified $S$. saprophyticus $\mathrm{S}_{67}$ peptidoglycan extract. After autopsy, kidneys and urinary bladder showed several histopathological changes both in cells and peptidoglycan injected mice, included: hydropic degeneration, glomerulus shrinkage, congestion of renal vessels, infiltration of inflammatory cells, and dekeratinization in urinary bladder.
\end{abstract}

\section{Introduction}

Staphylococcus saprophyticus is a member of coagulase negative staphylococci group that cause urinary tract infections; cystitis, urethritis and pyelonephritis in young women (1). Also it may cause Bacteremia (2), endophthalmitis (3), wound infection, eczema (4) and respiratory tract infections (5). This bacteria has the ability to produce urease which considered one of the important factor in establishing urinary tract infections (6).

The rigidity of bacterial cell wall is attributed to a macromolecule known as peptidoglycan; a complex polymer composed of alternating series of two major subunits, N-acetylmuramic (NAM) and $\mathrm{N}$-acetylglucosamin (NAG), attached to each NAM a string of tetrapeptide chain, cross linkages can form between those chains (7).

Peptidoglycan extracted from staphylococci and streptococci is known to cause septic shock in lab animals characterized by fever, inflammatory reactions, thrombocytopenia and multiple organ dysfunction syndrome $(8,9)$.

\footnotetext{
*Lecturer, Department of Biology, College of Science, University of Baghdad

**Assistant professor, Department of Biology, College of Science, University of Baghdad

***Assistant lecturer, Department of Biology, College of Science, University of Baghdad
} 
method described by De-Jonge (12), partially purified according to Amako et al. (13) and the purity was confirmed by the method of Umeda et al. (14).

\section{In vivo study}

According to the method described by Mctaggart et al. (15) the animals were transurethrally injected via catheter (0.6 $\mathrm{mm}$ in diameter) after applying a gentle pressure on animal abdomen in order to empty the urinary bladder from urine. The first group (group A) was injected with 0.2 $\mathrm{ml}$ of $S$. saprophyticus cell suspension in a concentration reached $10^{9} \mathrm{CFU} / \mathrm{ml}$ (phosphate buffer saline $\mathrm{pH}$ 7.2), the second group (group B) was injected with $3 \mathrm{mg} / 0.2 \mathrm{ml}$ of partially purified $S$. saprophyticus $\mathrm{S}_{67}$ peptidoglycan extract, while the third group (group C) was injected with $0.2 \mathrm{ml}$ of phosphate buffer saline $\mathrm{pH} 7.2$ and considered as control group.

Four days later, all groups were sacrificed, kidney and urinary bladder were submitted to histopathological study (16).

\section{Results and discussion \\ In vivo study}

1- kidney:

The histopathological study of mice kidney injected with cell suspension of $S$. $\left.\begin{array}{llllll}\text { saprophyticus } & \mathrm{S}_{67} & (1 & \mathrm{X} & 10^{9} & \mathrm{CFU} / \mathrm{ml}\end{array}\right)$ showed several pathological changes in comparison to control group (figure 1) represented by hydropic degeneration, glomerulus shrinkage, increase the glomerulus interstitial space as illustrated in figure 2., infiltration of inflammatory cells (figure 3 ).

While kidneys of mice injected with 3 $\mathrm{mg} / \mathrm{ml}$ of peptidoglycan developed hydropic degeneration, glomerulus shrinkage(figure 4), infiltration of inflammatory cells, increase in glumerular cell size in addition to accumulation of body fluids inside the renal tissue, consequently, led to edema formation (figure 5) and vessel congestion (figure 6). 2- urinary bladder

Figure 7 showed the cross section of urinary bladder of control mice while the urinary bladder of group A showed dekeratinization, necrosis in urothelial layer, in addition to infiltration of inflammatory cells in the lumen (figure 8). As illustrated in figure 9, similar histopathological changes; dekertinization, necrosis and infiltration of inflammatory cells were the characteristic features of the group B urinary bladder cross section.

Staphylococcus saprophyticus has high affinity to attach to renal cells by means of the extracellular materials $(15,17)$. Also some strains of $S$. saprophyticus produce proteins called surface associated proteins bind to renal cells (17) and slime materials aid in its attachment to eukaryotes (18).Gatermann and his coworkers (17) have pointed out that $S$. saprophyticus can cause necrosis to renal tubules, infiltration of inflammatory cells and urolithiasis.

Staphylococcus saprophyticus attachment to urothelial cells lining the urinary bladder is achieved via oligosaccharides receptors on these cells (4) can result in edema formation, swelling of cells, rupture of intracellular connections leading to dekartinization of urothelial layer and exposing the cells to bacterial colonization and immigration of macrophages and polymorphonuclear cells and other immunocompetent cells (17).

The peptidoglycan polymer was characterized by having many bioactivities, it can activate leukocytes, generate proinflammatory cytokines such as tumor necrosis factor alpha (TNF- $\alpha)$, interleukin-1 (IL-1), IL-6, and cause systemic inflammatory response syndrome (18). Peptidoglycan was also shown to mediate platelet aggregation in Staphylococcus aureus septicemia, induce tissue factor (TF) in monocytes, display procoagulant activity (19), stimulation of 
polymorphonuclear cells, induce mast cells to produce histamine, and increase the permeability of blood vessels (20). Due to its high molecular weight, it has antigenic capacity hence elicit acute and chronic immune response (21).

The present study showed that the peptidoglycan extracted from $S$. saprophyticus has the ability to cause damage to the renal system in mice similar to whole bacteria, therefore it can be concluded that this polymer may play an important role in its pathogenicity.

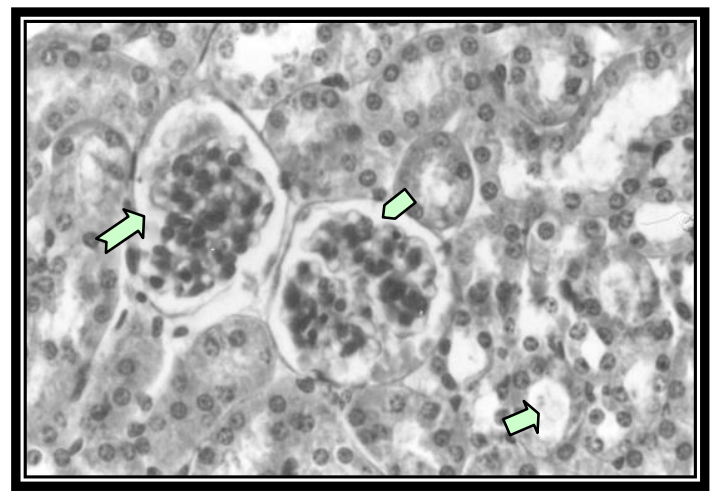

Figure 1: cross section in mouse kidney

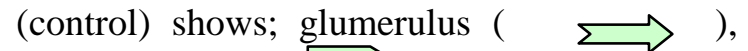
interstitial space ( $\square$ ) and the renal tubule $(\Rightarrow)$ at X400 magnification. H\&E.

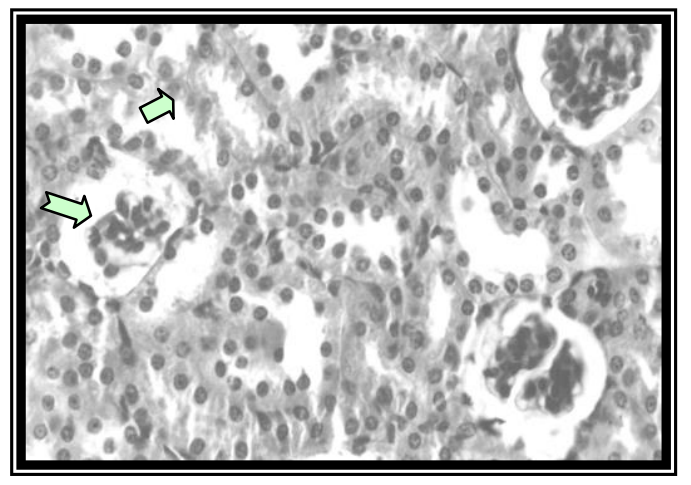

Figure 2: cross section in mice kidney injected with S. saprophyticus ( 1 x 109 CFU/ml) shows; hydropic degeneration

$(\vec{c})$ ), glumerulus shrinkage and increase of interstitial space $(\stackrel{\Longleftrightarrow}{)})$ at X400 magnification. H\&E

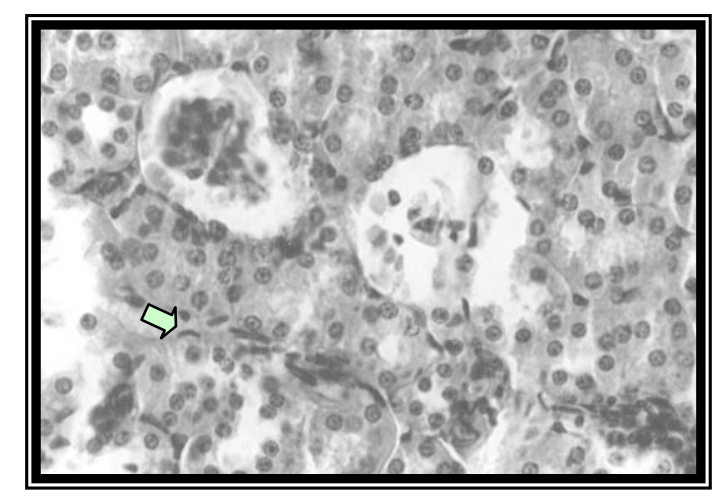

Figure 3: cross section in mice kidney injected with S. saprophyticus $(1 \times 109 \mathrm{CFU} / \mathrm{ml})$ shows the infiltration of inflammatory cells $(\vec{b})$ at X400 magnification. $\mathrm{H} \& \mathrm{E}$

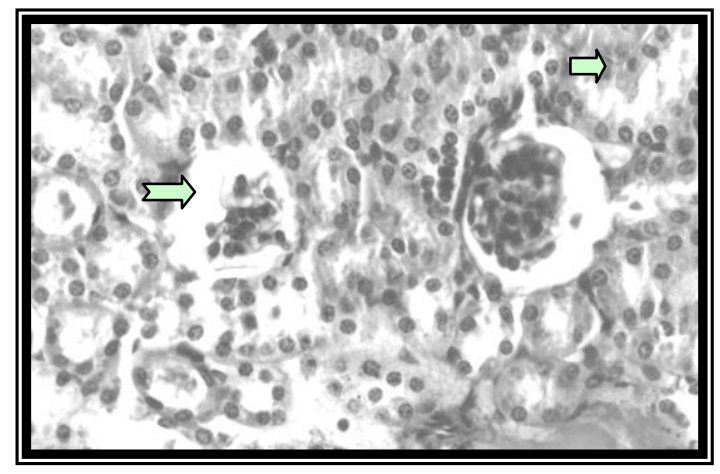

Figure 4: cross section in mice kidney injected with S. saprophyticus peptidoglycan $(3 \mathrm{mg} / \mathrm{ml})$ shows; hydropic degeneration ( $\Rightarrow$ ), glumerulus shrinkage and increase of interstitial space $(\Longleftrightarrow)$ at X400 magnification. $\mathrm{H} \& \mathrm{E}$

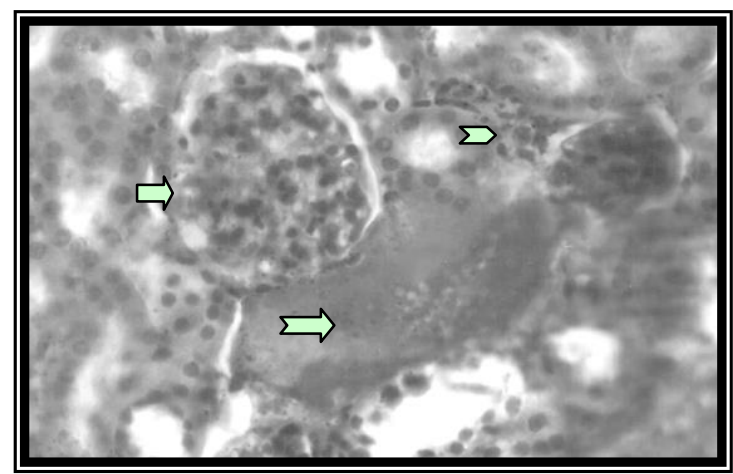

Figure 5: cross section in mice kidney injected with S. saprophyticus peptidoglycan $(3 \mathrm{mg} / \mathrm{ml})$ shows; infiltration of inflammatory cells $(\Sigma)$, edema in glumerulus size $(\vec{\longrightarrow})$ and increase magnification. $\mathrm{H} \& \mathrm{E}$ 


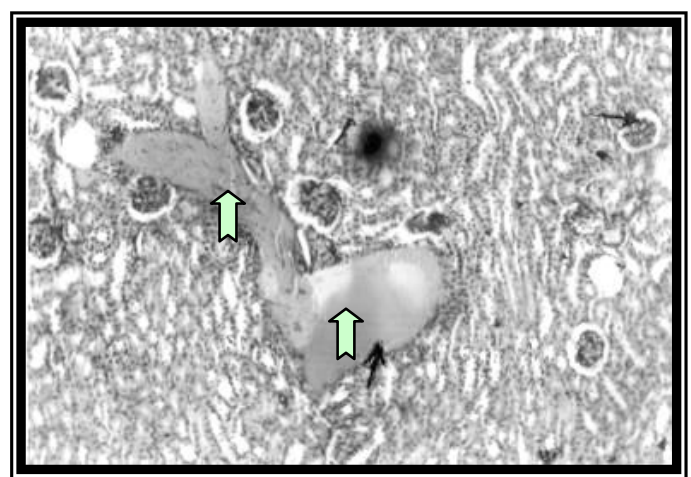

Figure 6: cross section in mice kidney injected with $\mathrm{S}$. saprophyticus peptidoglycan $(3 \mathrm{mg} / \mathrm{ml})$ shows; congestion of blood vessel ( $\Longleftrightarrow$ ) at X100 magnification. $\mathrm{H} \& \mathrm{E}$

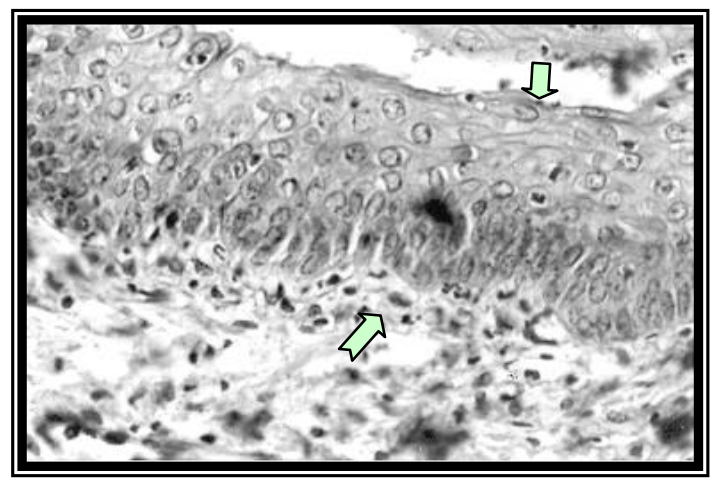

Figure 7: cross section in urinary bladder of mice (control) showed the urothelial layer

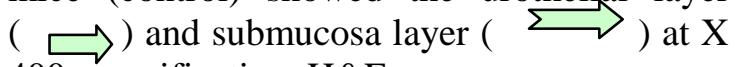
400 magnification. $\mathrm{H} \& \mathrm{E}$

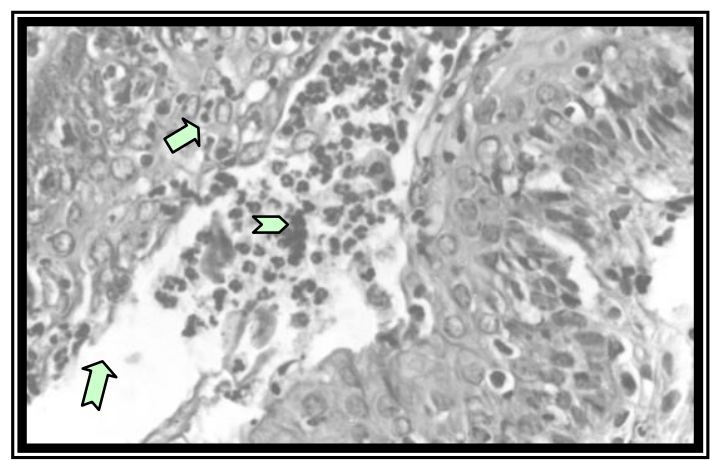

Figure 8: cross section in mice urinary bladder injected with S. saprophyticus (1 $x$ inflammatory cells $\left(\stackrel{\text { the }}{\Sigma}\right.$ infiltration ${ }_{\text {necrosis }(~}{ }^{\text {of }}$ ) and dekertinization ( $\Longleftrightarrow \quad$ ) at X400 magnification. $\mathrm{H} \& \mathrm{E}$

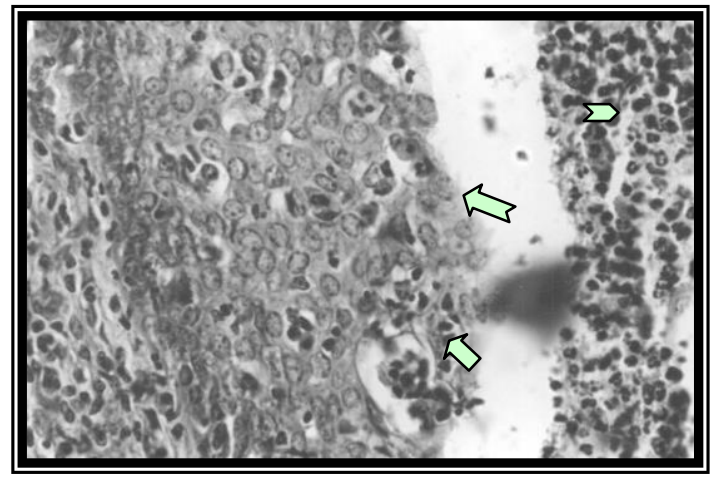

Figure 9: cross section in mice urinary bladder injected with S. saprophyticus peptidoglycan (3 $\mathrm{mg} / \mathrm{ml}$ ) shows the infiltration of inflammatory cells $(\Sigma)$ ), necrosis $(\square$ and dekertinization ( $\sum$ at X400 magnification. $\mathrm{H} \& \mathrm{E}$

\section{Reference:}

1- Kuroda, M., A. Yamashita, H. Hirakawa, M. Kumano, K. Morikawa, M. Higashide, A. Maruyama, Y. Inose, K. Matoba, H. Toh, S. Kuhara, M. Hattori, and T. Ohta. (2005). Whole genome sequence of Staphylococcus saprophyticus reveals the pathogenesis of uncomplicated urinary tract infection. Proc. Natl. Acad. Sci. 102:13272-13277

2- Golledge, C. L. (1988). Staphylococcus saprophyticus Bacteremia. J. Infect. Dis. 157: 215.

3- Parkkari, M.; Paivarinta, H. and Salminen, L. (1995). The treatment of endophthalmitis cataract surgery. Review of 26 cases. J. Ocul. Pharmacol. Ther. 11(3): 349-359.

4- Hovelius, B. and Mardh, P. (1984). Staphylococcus saprophyticus as a common cause of urinary tract infection. Rev. Infect. Dis. 6(3):328 - 337.

5- Axel, L., Josef, B., Gerhard, P. and Gerhard, U. (1994). Cell electrophoretic discrimination of Staphylococcus strains of different origin. Zentrabl. Bacteriol. 280: 515-519.

6- Rupp, M. E.; Soper, D. E. and Archer, G. L. (1992). Colonization of the female genital tract with Staphylococcus saprophyticus. J. Clin. Microbiol. 30 (11): 2975-2979. 
7- Brooks, G., Batel, J. and Morse. (2004). Medical microbiology $23^{\text {rd }}$ ed. Appleton and Lange. pp. 20-21.

8- Bera, A., Biswas, R., Herbert, S. and Götz, F. (2006). The Presence of Peptidoglycan O-Acetyltransferase in Various Staphylococcal Species Correlates with Lysozyme Resistance and Pathogenicity. Infect Immun. 74(8): 45984604.

9- Myhre, A. E. Stuestol, J. F., Dahle, M. K., Overland, G., Thiemermann, C., Foster, S. J., Lilleaasen, P., Aasen, A. O., Wang, J. E. (2004). Organ Injury and Cytokine Release Caused by Peptidoglycan are dependent on the structural integrity of the Glycan chain. Infect. Immun. 72: 1311-1317.

10-Leemans, J., Heikens, van Kessel, K., Florquin, S. and van der Poll, T. (2003). Lipoteichoic Acid and Peptidoglycan from Staphylococcus aureus Synergistically Induce Neutrophil Influx into the Lungs of Mice. Clinical and Diagnostic Laboratory Immunol. 10 (5): 950-953.

11-Athraa, S., Fleih, M. and AlMathkhury, H. (2007). Purification and extraction of peptidoglycan from $S$. saprophyticus. Al-Nahrain University Journal for science. In press.

12-De Jonge, B. L.; Cheng, Y. S.; Gage, D. and Tomas, Z. A. (1992). Peptidoglycan composition of highly methicillin-resistant Staphylococcus aureus strain. J. Biol. Chem. 267(16):11248-11254.

13-Amako, K. ; Umeda, A. and Murata, K. (1982). Arrangement of peptidoglycan in the cell wall of Staphylococcus spp. J. Bacteriol. 150 (2): 844 - 850.
14- Umeda, A.; Ueki, Y. and Amako, K.(1987).Structure of the Staphylococcus aureus cell wall determined by the freezesubstitution method. J. Bacteriol.169(6):2482-2487. 15-Mctaggart, L. A.; Rigby, R. C. and Elliot, T. S. (1990). The pathogenesis of urinary tract infections associated with Escherichia coli, Staphylococcus saprophyticus and S. epidermidis. J. Med. Microbiol. 32:135-141.

16-Humason, G. 1972. Animal tissue technique $3^{\text {rd }}$ ed. W.H. Freeman Company, San Francisco.pp.641.

17- Gatermann, S. (1997). Regulation of Staphylococcus saprophyticus adhesions. Nova. Acta. Zeopoldina.301:189-194.

18- Wang, Z., Liu, C., and Dziarski, R. (2000). Chemokines are the main proinflammatory mediators in human monocytes activated by Staphylococcus aureus, peptidoglycan, and endotoxin. J. Biol Chem.;275(27):20260-20267.

19- Mattsson E, Herwald H, Bjorck L, Egesten A. (2002) Peptidoglycan from Staphylococcus aureus induces tissue factor expression and procoagulant activity in human monocytes. Infect Immun. 70(6):3033-3039)

20- Van Amersfoort, E. Van Berkel, T. and Kuiper, J. (2003). Receptors, Mediators, and Mechanisms Involved in Bacterial Sepsis and Septic Shock. Clinical Microbiol. Reviews. 16(3): 379-414.

21- Boneca, I. G. (2005). The role of peptidoglycan in pathogenesis. Curr. Opin. Microbiol. 8(1):46-53. 


\section{دور البيتيدوكلايكان في امراضية Staphylococcus saprophyticus في الفئران}

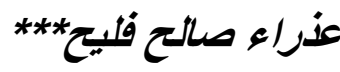

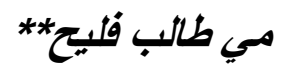

حارث جبار فه المذخوري

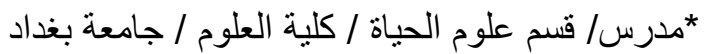

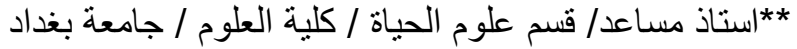

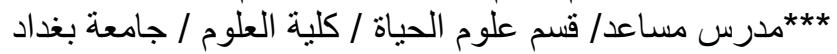

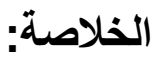

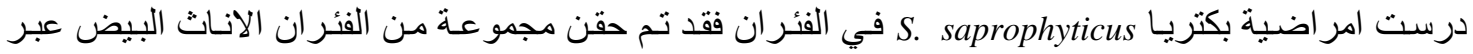

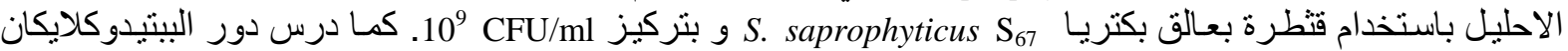

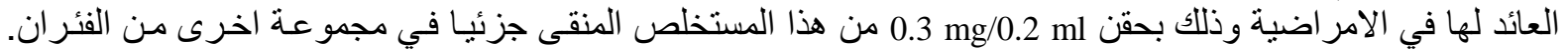

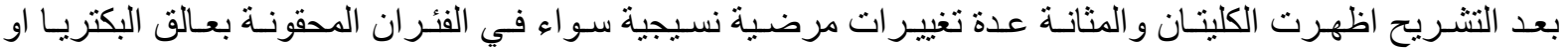

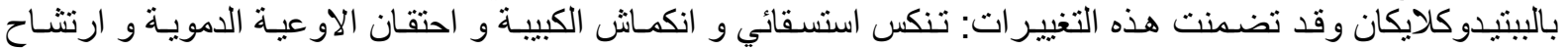
الخلايا الالتهابية و فقدان طبقة الكير اتين في المثانة. 